\title{
Atuação da Autoridade Policial e do Poder Judiciário no Combate À ViolêNCIA Doméstica Contra a Mulher na Cidade de São Luís/MA ${ }^{1}$
}

\author{
Bruno Denis Vale Castro* \\ Artenira da Silva e Silva**
}

\begin{abstract}
1 Considerações iniciais. 2 A rede de enfrentamento à violência doméstica no Brasil: avanços e marcos legislativos. 3 A Delegacia Especial da Mulher de São Luís/MA: dificuldades no enfrentamento da violência doméstica contra a mulher. 3. 1 A DEM de São Luís e as peculiaridades no atendimento à mulher vítima de violência doméstica. 4 A Vara Especializada de Violência Doméstica e Familiar Contra a Mulher: atuação na cidade de São Luís. 4. 1 Análise dos dados dos processos de violência doméstica que tramitaram na Vara Especializada de Violência Doméstica e Familiar Contra a Mulher da Comarca de São Luís de acordo com levantamento do ano de 2014. 5 Considerações finais. Referências.
\end{abstract}

\section{RESUMO}

Considerando os números crescentes de casos de violência doméstica contra a mulher e o déficit de estudos voltados para uma avaliação da estrutura das políticas públicas a níveis locais e seus efeitos para coibir a violência de gênero, este artigo tem o objetivo de realizar um levantamento de informações e dados referentes às prestações dos serviços e atuação da Delegacia Especial da Mulher e da Vara Especializada da Mulher e da Violência Doméstica de São Luís/MA responsáveis, respectivamente, pelo atendimento e julgamento dos possíveis crimes de violência doméstica contra a mulher, de modo a discutir

1 Este artigo é fruto dos resultados da pesquisa intitulada: "POLÍTICAS PÚBLICAS E ASSISTÊNCIA JURÍDICA NA CIDADE DE SÃO LUÍS: enfrentamento da violência doméstica contra a mulher", financiada pelo CNPq/PIBIC-UFMA e desenvolvida no Núcleo de Estudos de Direito Constitucional - UFMA (NEDC/UFMA), durante os anos 2014/2015.

* Graduado em Direito (UFMA), Mestrando em Direito e Instituições do Sistema de Justiça da UFMA (PPGDIR/UFMA). Membro do Núcleo de Estudos de Direito Constitucional (NEDC/UFMA). Assessor de Promotor de Justiça (MPMA). Desenvolve pesquisa dentro das linhas de pesquisa de Constituição e Justiça, Direito Constitucional, Direito Penal Tributário e Instituições do Sistema de Justiça. E-mail: < brunodvcastro@hotmail.com>.

** Pós-doutora em Psicologia e Educação pela Universidade do Porto. Doutora em Saúde Coletiva pela Universidade Federal da Bahia. Mestre em Saúde e Ambiente pela Universidade Federal do Maranhão, Graduada em Psicologia pela Pontifícia Universidade Católica de São Paulo. Docente e pesquisadora do Departamento de Saúde Pública e do Mestrado em Direito e Instituições do Sistema de Justiça da Universidade Federal do Maranhão. Coordenadora de linha de pesquisa do Observatório Ibero Americano de Saúde e Cidadania e coordenadora do Observatorium de Segurança Pública (PPGDIRUFMA/CECGP). Psicóloga Clínica e Forense. E-mail: < artenirassilva@hotmail.com>. 
as principais dificuldades encontradas por esses órgãos em suas atuações. Evidenciou-se que o atendimento a mulheres vítimas de violência doméstica ou intrafamiliar exige uma qualificação técnica específica, uma vez que demanda uma atuação transdisciplinar daqueles que atuam frente ao fenômeno aludido, seja nas Delegacias Especiais da Mulher seja nas Varas Especializadas. Além disso, concluiu-se que a Vara de Violência Doméstica e Familiar Contra a Mulher da Cidade de São Luís/MA precisa ressignificar a sua atuação diante do inexpressivo número de processos que possuem decisões de mérito e condenações transitadas em julgado desde sua criação em 2008. Apenas focar em concessão de medidas protetivas de urgência, considerando-as ações "satisfativas", mostra-se como sendo uma restrição demasiada do escopo de proteção que a Lei 11.340/2006 pretende alcançar. Sem instruções processuais de cunho explicitamente transdisciplinar que visibilize o fenômeno da violência de gênero em suas especificidades e complexidade, não há garantia efetiva de proteção de mulheres violentadas, tampouco justiça.

Palavras-chave: Violência doméstica. Autoridade Policial. Poder Judiciário. São Luís/MA.

\section{CONSIDERAÇÕES INICIAIS}

A violência contra a mulher figura no século XXI como um fenômeno de destaque diante dos números alarmantes de sua incidência em detrimento da crescente conscientização global acerca dos direitos humanos.

De origens associadas a razões biológicas, sociais, psicanalíticas e históricas, o problema assume dimensões que ultrapassam as fronteiras dos países, tornando-se prioridade na agenda mundial.

No Brasil, várias políticas públicas voltadas para a proteção da mulher foram implantadas principalmente a partir da Constituição de 1988, considerada um divisor de águas no constitucionalismo brasileiro ao inaugurar um sistema baseado em valores universais de igualdade, trazendo em seu texto um conjunto de ações e garantias afirmativas para a promoção dos direitos das mulheres. Além disso, a Organização Mundial de Saúde (OMS), em 1994, definiu oficialmente a violência contra a mulher como: "todo ato que produz dano físico, sexual ou psicológico à mulher, incluindo as consequências desses atos, a coerção, a privação arbitrária da liberdade, independente se ocorre na instância pública ou privada."1

Nesse contexto, avanços na política brasileira de proteção da mulher, como a criação da Secretaria de Políticas Públicas para Mulheres, a afirmação do Pacto Nacional pelo Enfrentamento da Violência Contra as Mulheres e as previsões políticas previstas na Lei Maria da Penha, vêm contribuindo significativamente para o tratamento do problema da violência 
contra a mulher no país. Ademais, os esforços para o enfrentamento à violência contra a mulher também são verificados na construção da Rede de Enfrentamento à Violência contra a Mulher, arcabouço normativo que reúne ações integradas dos entes federativos de forma a prestar serviços de prevenção e atendimento às mulheres vítimas desse tipo de violência.

Diante de todo esse contexto, a Lei $n^{0} 11.340 / 2006$, Lei Maria da Penha, aparece como um marco importante para o aperfeiçoamento dessa Rede de combate à violência, tendo a finalidade de coibir a violência doméstica e familiar contra a mulher, alinhando-se ao fundamento jurídico expresso no $\S 8^{\circ}$ do art. 226 da Constituição Federal brasileira, o qual estabelece o dever do Estado de criar mecanismos para coibir a violência no âmbito das relações domésticas.

Não obstante a importância desses avanços, há ainda um número crescente de casos de violência doméstica contra a mulher e um grande déficit de estudos voltados para uma avaliação da estrutura dessas políticas públicas a níveis locais e seus efeitos para coibir a violência de gênero. Esse estudo defende que, além da percepção sobre a importância da proteção jurídica, torna-se essencial refletir sobre a atuação dos órgãos do poder público que atuam diretamente na efetividade das políticas públicas direcionadas à mulher vítima de violência, tendo em vista que tais esclarecimentos possibilitam o diagnóstico das atuais dificuldades encontradas na concretização dos serviços prestados às vítimas, bem como a propositura de alternativas viáveis para o enfrentamento da violência doméstica e/ou intrafamiliar contra as mulheres.

Diante disso, tem-se o objetivo de realizar um levantamento de informações e dados referentes às prestações dos serviços e à atuação da Delegacia Especial da Mulher e da Vara Especializada de São Luís/MA responsáveis, respectivamente, pelo atendimento e pelo julgamento dos possíveis crimes de violência doméstica contra a mulher, de modo a discutir as principais dificuldades encontradas por esses órgãos em suas atuações.

Quanto aos procedimentos e às técnicas de pesquisa, adotou-se a pesquisa de campo, a revisão bibliográfica, a revisão normativa e a pesquisa documental para fazer a discussão proposta. As informações foram coletadas em livros especializados, revistas nacionais e dados regionais, além de informações obtidas junto à Delegacia Especial da Mulher (Delegada Titular da Mulher) e à Vara Especializada de Violência Doméstica e Familiar Contra a Mulher (assessores jurídicos da Vara), todos localizados e com atuação na cidade de São Luís.

A amostra de profissionais entrevistados para a obtenção de dados referentes a cada órgão se deu pela estratificação. $\mathrm{O}$ critério de inclusão para identificar esses profissionais foi o atendimento direto à vítima, no primeiro atendimento ou no acolhimento, na realização do serviço finalístico do órgão, ou no encaminhamento da vítima a outro órgão da rede de proteção.

Assim, este trabalho realiza, em um primeiro momento, uma pequena explanação sobre a Rede de Enfrentamento à Violência Doméstica, de modo a esclarecer como se deu no Brasil 
o avanço das políticas públicas voltadas para a proteção da mulher vítima de violência e como se dá o funcionamento da rede de enfrentamento, na qual a autoridade policial e os órgãos do Poder Judiciário estão incluídos, descrevendo, por fim, a definição dessa modalidade de violência segundo a Lei $n^{\circ}$. 11. 340/06.

No segundo momento, são realizadas discussões e apontadas reflexões tendo por base as informações e dados obtidos junto à Delegacia da Mulher e à Vara Especializada de Violência Doméstica e Familiar Contra a Mulher com atuações na cidade de São Luís/ MA sobre a atuação desses órgãos e considerações qualiquantitativas sobre os dados e informações obtidas.

\section{A REDE DE ENFRENTAMENTO À VIOLÊNCIA DOMÉSTICA NO BRA- SIL: AVANÇOS E MARCOS LEGISLATIVOS}

Waiselfisz $z^{2}$ destaca que a ideologia patriarcal, que define as relações de poder entre homens e mulheres na sociedade - e que permeia a cultura, as instituições e o próprio sistema de justiça criminal - tem constituído um forte obstáculo para os avanços em direção à garantia de igualdade de direitos para as mulheres.

A verdade é que discussões voltadas para o enfrentamento da violência contra a mulher são recentes no país. Até a década de 1970, a tese de legítima defesa da honra era aceita nos tribunais para inocentar maridos que assassinavam suas mulheres, como o famoso caso Doca Street, de 1977, que gerou uma forte reação do movimento feminista. Nesse mesmo período, debatia-se no meio jurídico se o marido poderia ser sujeito ativo do crime de estupro contra sua esposa, uma vez que era dever dos cônjuges manter relações sexuais. ${ }^{3}$

Como resultado das reivindicações oriundas do movimento feminista brasileiro, o Programa de Assistência Integral à Saúde da Mulher (PAISM) foi criado em 1983 com o objetivo de atender à mulher em sua integralidade, especialmente quando em situações de violência doméstica. No ano de 1985, foi institucionalizado o Conselho Nacional dos Direitos da Mulher (CNDM), oportunidade em que foram criadas as primeiras Delegacias Especializadas no Atendimento à Mulher (DEAMs). No ano seguinte, registrou-se a criação da primeira Casa Abrigo para mulheres, instituída pela Secretaria de Segurança Pública de São Paulo com a finalidade de abrigar as mulheres em situação de risco de morte. ${ }^{4}$

Apesar de a Constituição de 1988 ter igualado as funções familiares entre homens e mulheres, apenas em 1995, a Lei nº 9.520 revogou o Artigo 35 do Código de Processo Penal, que estabelecia que a mulher casada não poderia exercer o direito de queixa sem a autorização do marido, salvo quando fosse contra ele, ou que esta estivesse separada. Em 2000, a Lei $\mathrm{n}^{\mathrm{O}} .2 .372$, que propunha medidas protetivas para a mulher vítima de violência doméstica - com o afastamento do agressor da habitação - foi totalmente vetada pelo então Presidente da República. 
No ano de 2003, para coordenar os serviços de atendimento à mulher em situação de violência, a Lei n⿳ ${ }^{\circ}$ 10.683/03 transformou a Secretaria de Estado dos Direitos da Mulher, órgão integrante do Ministério da Justiça, em Secretaria Especial de Políticas para Mulheres, órgão integrante da Presidência da República, o que representou mais um passo em direção à constituição de uma Rede de Enfrentamento à Violência contra a Mulher, tendo em vista que foram garantidos recursos para a criação de serviços e implementação de políticas públicas que supostamente deveriam atuar integradas. ${ }^{5}$

A denominação Rede de Enfrentamento à Violência Contra as Mulheres reúne termos de alcance amplo, de modo a englobar uma variedade de serviços e complexidade na organização do atendimento. Observa-se a existência de órgãos e serviços, que, embora não estejam diretamente envolvidos na assistência às mulheres em situação de violência, desempenham um relevante papel no que tange ao combate e à prevenção da violência e à garantia de direitos das mulheres e por isso passam a ser incluídos no rol dos integrantes da "rede de enfrentamento à violência contra as mulheres". Nesse contexto, essa Rede abrange, além dos serviços responsáveis pelo atendimento, os agentes governamentais e não governamentais formuladores, fiscalizadores e executores de políticas voltadas para as mulheres, para as universidades, para o movimento de mulheres, entre outros. ${ }^{6}$

O conceito de rede de enfrentamento à violência contra as mulheres diz respeito à atuação articulada entre as instituições/serviços governamentais, não governamentais e a comunidade, visando ao desenvolvimento de estratégias efetivas de prevenção e de políticas que garantam o empoderamento e a construção da autonomia das mulheres, os seus direitos humanos, a responsabilização dos agressores e a assistência qualificada às mulheres em situação de violência. ${ }^{?}$

A fim de contemplar esses propósitos, a rede de enfrentamento é composta por: agentes governamentais e não governamentais formuladores, fiscalizadores e executores de políticas voltadas para as mulheres (organismos de políticas para as mulheres, ONGs feministas, movimento de mulheres, conselhos dos direitos das mulheres, outros conselhos de controle social; núcleos de enfrentamento ao tráfico de mulheres, etc.); serviços/programas focando a responsabilização dos agressores; as universidades; os órgãos federais, estaduais e municipais responsáveis pela garantia de direitos (à habitação, à educação, ao trabalho, à seguridade social, cultura) e serviços especializados e não especializados de atendimento às mulheres em situação de violência.

Sendo assim, essa Rede de atendimento corresponde ao conjunto de ações e serviços de diferentes setores (em especial, da assistência social, da justiça, da segurança pública e da saúde), que visam à ampliação e à melhoria da qualidade do atendimento, à identificação e ao encaminhamento das mulheres em situação de violência.

A respeito dos marcos legislativos voltados para o combate e prevenção da violência contra a mulher, sancionada pelo Presidente Luiz Inácio Lula da Silva, a Lei 10.745/03 é 
composta por um conjunto de dispositivos normativos dedicados especialmente à previsão de programas e atividades voltados à divulgação e à comemoração das conquistas da mulher no âmbito da sociedade civil, de forma a promover iniciativas que consolidem a igualdade e inserção da mulher na sociedade brasileira.

Entretanto, o maior marco legislativo do combate à violência contra a mulher no Brasil foi a sanção da Lei 11.340/06, conhecida popularmente como Lei Maria da Penha. Essa lei surgiu como importante instrumento infraconstitucional de concretização dos preceitos constitucionais por meio da criação de mecanismos destinados a coibir a violência doméstica e familiar contra a mulher. $O$ mencionado dispositivo legal estabeleceu a articulação de uma política pública concretizada por meio de ações integradas dos entes federativos e organizações não governamentais, de forma a fomentar um atendimento especializado para a mulher em situação de violência. ${ }^{8}$

A Lei Maria da Penha (LMP), conforme destacado por Calazans e Cortes, ${ }^{9}$ representa um dos mais empolgantes e interessantes exemplos de amadurecimento democrático, pois contou na sua formulação com a participação ativa de organizações não governamentais feministas, Secretaria de Política para Mulheres, academia, operadores do Direito e o Congresso Nacional. ${ }^{10}$ Conforme também indica Waiselfisz: ${ }^{11}$

Em termos mais gerais, uma inovação importante da LMP é que esta procurou tratar de forma integral o problema da violência doméstica, e não apenas da imputação de uma maior pena ao ofensor. Com efeito, a nova legislação ofereceu um conjunto de instrumentos para possibilitar a proteção e o acolhimento emergencial à vítima, isolando-a do agressor, ao mesmo tempo que criou mecanismos para garantir a assistência social da ofendida. Além disso, a lei previu os mecanismos para preservar os direitos patrimoniais e familiares da vítima; sugeriu arranjos para o aperfeiçoamento e efetividade do atendimento jurisdicional; e previu instâncias para tratamento do agressor.

Ainda é importante destacar o Pacto Nacional pelo Enfrentamento da Violência Contra as Mulheres. ${ }^{12}$ Estabelecido no ano de 2007 pelo Governo Federal, esse Pacto contempla, dentre outras medidas, a criação dos juizados de violência doméstica e familiar contra a mulher, previstos na Lei Maria da Penha, o fortalecimento da rede de atendimento às vítimas de violência, com a criação de novas delegacias especializadas no atendimento à mulher, defensorias públicas da mulher, casa abrigo, estabelece o atendimento às mulheres em situação de violência nos Centros de Referência de Assistência Social (CRAS) e campanhas educativas de prevenção da violência doméstica e familiar.

Nesse contexto, a atuação governamental passou a assumir, não somente o apoio a serviços emergenciais e a campanhas isoladas, mas também uma atuação ampla que contempla ações, como a capacitação de agentes públicos para prevenção e atendimento das vítimas; a criação de normas e padrões de atendimento; o aperfeiçoamento da legislação; o incentivo à constituição de redes de serviços; o apoio a projetos educativos e culturais de prevenção à 
violência e a ampliação do acesso das mulheres à justiça e aos serviços de Segurança Pública. Nesse aspecto, a atuação integrada dos entes federativos tornou-se imprescindível para o fortalecimento de uma rede de enfrentamento da violência contra a mulher no Brasil.

Nesse sentido, a Secretaria de Políticas para Mulheres lançou diretrizes para uma atuação coordenada dos organismos governamentais nas três esferas da federação, de forma a estruturar a Rede de Atendimento à Mulher em situação de violência nos estados, nos municípios e no Distrito Federal, por meio do incentivo à criação de políticas no âmbito de cada ente envolvido no Pacto.

Corroborando com esse posicionamento do Governo Federal, o art. $9^{\circ}$ da Lei Maria da Penha prevê, como uma das estratégias de enfrentamento da violência doméstica e familiar contra a mulher, que

a assistência à mulher em situação de violência doméstica e familiar será prestada de forma articulada e conforme os princípios e as diretrizes previstos na Lei Orgânica da Assistência Social, no Sistema Único de Saúde, no Sistema Único de Segurança Pública, entre outras normas e políticas públicas de proteção. ${ }^{13}$

Também a Central de Atendimento à Mulher - Ligue 180- constitui outro instrumento importante para o aperfeiçoamento da rede de proteção à mulher em situação de violência. $\mathrm{O}$ serviço foi criado pela Secretaria de Políticas para Mulheres com o escopo de promover a orientação de mulheres em situação de violência sobre seus direitos e sobre os serviços de proteção correspondente, além de auxiliar no monitoramento da rede, por meio da reunião de dados que compõem o diagnóstico da violência no país. Funciona por meio da disponibilização de um número de utilidade pública, que pode ser acessado gratuitamente por mulheres de todo o território nacional.

Entende-se necessário destacar ainda neste tópico da discussão que a Lei 11.340/06, ${ }^{14}$

[...] cria mecanismos para coibir e prevenir a violência doméstica e familiar contra a mulher, nos termos do $\S 8$ o do art. 226 da Constituição Federal, da Convenção sobre a Eliminação de Todas as Formas de Violência contra a Mulher, da Convenção Interamericana para Prevenir, Punir e Erradicar a Violência contra a Mulher e de outros tratados internacionais ratificados pela República Federativa do Brasil; dispõe sobre a criação dos Juizados de Violência Doméstica e Familiar contra a Mulher; e estabelece medidas de assistência e proteção às mulheres em situação de violência doméstica e familiar. (Art. $1^{\circ}$ ).

Assim, a referida lei define o conceito de violência doméstica e familiar contra a mulher de forma clara e objetiva como "[...] qualquer ação ou omissão baseada no gênero que lhe cause morte, lesão, sofrimento físico, sexual ou psicológico e dano moral ou patrimonial.” $\left(\right.$ art. $\left.5^{\circ}\right) .{ }^{15}$ Além disso, define tipos e formas de violência rompendo a ideia de que a violência se resumia aos tipos de violência que deixassem marcas no corpo (como violência física e sexual). O referido dispositivo legal avança categorizando a violência psicológica, a violência patrimonial e violência moral também como formas de violências importantes de 
serem efetivamente punidas e combatidas, especialmente pela sua ciclicidade e pela intensidade com que comprometem a saúde emocional da mulher, tolhendo-lhe a autoestima, a autodeterminação e até sua motivação para viver, ou seja, matando-a em vida.

\section{A DELEGACIA ESPECIAL DA MULHER DE SÃO LUÍS/MA: DIFICULDA- DES NO ENFRENTAMENTO DA VIOLÊNCIA DOMÉSTICA CONTRA A MULHER}

A atuação da autoridade policial em crimes de violência doméstica contra a mulher está prevista no capítulo III, artigos 10 a 12 da Lei no . 11. 340, de 2006 (Lei Maria da Penha). A Cidade de São Luís/MA possui apenas uma Delegacia Especial da Mulher-DEM, localizada na Avenida Beira Mar, Centro, responsável por toda a demanda de casos de crimes de violência doméstica ocorridos na capital. Em entrevista com a Delegada de Polícia titular da DEM da capital, foi informado que atualmente existem apenas 19 Delegacias Especiais da Mulher em todo o Estado do Maranhão, contando com a unidade da capital, destacando que, entre outras dificuldades, a principal é a falta de funcionários, tendo em vista a deman$\mathrm{da}^{16}$. Destaque-se ainda que a referida delegacia atua com o mesmo contingente de pessoal e material há quase uma década, tendo, em 2016, 8 estagiários suprimidos de seu quadro de funcionários. Nesse mesmo período, o número de denúncias de violências contra mulheres registrados diariamente na delegacia em questão tem crescido ano após ano.

Esclareceu-se que os procedimentos de atuação se dão pelo atendimento a mulheres vítimas de violência de gênero, não envolvendo crimes que não tenham relação direta com a violência de gênero, estando a violência doméstica dentro desses crimes.

Após o registro da ocorrência pela vítima, são notificadas e ouvidas as testemunhas, colhidas as eventuais provas e encaminhamento da vítima para exame de corpo de delito, quando necessário. $\mathrm{O}$ inquérito policial, após realizado relatório final, é encaminhado para a Vara Criminal Especializada e consequentemente dada vista ao Ministério Público.

Todo esse procedimento de atendimento na DEM de São Luís/MA à mulher vítima de violência doméstica parece eficiente e satisfatório, mas não. Em visita realizada na referida Delegacia Especializada, constatou-se que não há médico legista especializado para a realização dos exames de corpo de delitos nas vítimas, uma vez que só existe um Instituto Médico Legal-IML na cidade de São Luís/MA com médicos legistas responsáveis pelo atendimento geral, sem divisão de especialidade (o que, além de redundar em atrasos na juntada dos laudos nos inquéritos, impossibilita uma prestação de serviço adequado e humanizado à vítima). Ademais, foi indicado pela própria Delegada a existência de um número insuficiente de escrivães e agentes de polícia atuando na Delegacia Especializada da Mulher.

Essa carência no atendimento inicial se estende por toda trajetória da mulher vítima de violência que, ao procurar o amparo do Poder do Estado, acaba por se expor a outro tipo 
de violência, uma violência institucional, uma vez que não tem o seu direito de proteção assegurado por ingerência e omissão do poder estadual, além da falta de acesso a meios eficientes e capazes de oferecer e garantir minimamente a sua proteção. O Ministério da Saúde ${ }^{17}$ define Violência Institucional como aquela exercida nos/pelos próprios serviços públicos, por ação ou omissão. Pode incluir desde a dimensão mais ampla da falta de acesso à saúde, por exemplo, até a má qualidade dos serviços prestados. Abrange desde abusos cometidos em virtude das relações de poder desiguais entre usuários e profissionais dentro das instituições, até atuações profissionais imperitas, imprudentes e ou omissas.

O que se destaca aqui não é a ineficiência ou omissão no atendimento das vítimas pelos profissionais que atuam na DEM de São Luís, mas a falta de orçamento público destinado para essa única Delegacia da Mulher na cidade de São Luís/MA, o que acarreta, conforme relatou a Delegada, no atendimento insatisfatório por falta de corpo técnico, estrutura física da Delegacia e número de servidores suficiente para dar conta da instrução de quase mil inquéritos anuais.

\section{1 A DEM DE SÃO LUÍS E AS PECULIARIDADES NO ATENDIMENTO À MULHER VÍTIMA DE VIOLÊNCIA DOMÉSTICA}

A Delegada destacou ainda que, na atuação junto à mulher vítima de violência doméstica, existem aspectos que fogem da esfera estrita da atuação policial. Elucidou-se que a atuação em crimes de violência doméstica exige uma qualificação técnica específica no que tange à compreensão dos fenômenos da violência doméstica e da violência de gênero, de modo que o profissional esteja sempre atento à vulnerabilidade da vítima, em suas mais diferentes facetas, além da necessidade de a autoridade policial ter a capacidade de realizar o encaminhamento da vítima para a defensoria pública e para a casa abrigo da mulher, educação jurídica das vítimas quanto a seus direitos e quanto à atuação de toda a rede de proteção que existe para a mulher vítima de violência doméstica.

Autores como Menezes ${ }^{18}$ destacam a dependência financeira da vítima como um dos principais fatores relacionados à resistência e ao medo da vítima em denunciar o agressor, uma vez que aquele que agride pode também ser o principal mantenedor da casa. Novas pesquisas, inclusive a realizada pela Vara de Violência Doméstica e Familiar Contra a Mulher da Comarca de São Luís, sobre o perfil da vítima de violência doméstica têm demonstrado que muitas das vítimas possuem atividade remunerada, ${ }^{19}$ o que chama a atenção para outros fatores que compõe a vulnerabilidade da vítima: falta de apoio familiar para o prosseguimento das denúncias, introjeção de valores sociais e religiosos que imputam à mulher a "necessidade" de sofrer calada a fim de não "prejudicar" o pai de seus filhos, marido ou ex-marido e até a vinculação afeto sexual passada ou presente mantida com o agressor. 
A DEM de São Luís/MA informou que, no ano de 2014, foram iniciados cerca de 900 (novecentos) inquéritos policiais para investigar possíveis casos de violência contra a mulher. Isso evidencia que a violência de gênero contra a mulher constitui um grave problema de saúde e segurança pública crescentes no município de São Luís/MA.

A estimativa feita pelo Mapa da Violência 2015: homicídio de mulheres no Brasil, com base em dados de 2013 do Ministério da Saúde, alerta para o fato de ser a violência doméstica e familiar a principal forma de violência letal praticada contra as mulheres no Brasil. ${ }^{20}$

É importante destacar que, apesar de a Lei Maria Penha não ter como foco o homicídio de mulheres, parte-se do pressuposto de que a violência doméstica ocorre em ciclos, em que, "muitas vezes, há um acirramento no grau de agressividade envolvida, que, eventualmente, redunda (muitas vezes de forma inesperada) na morte do cônjuge", ${ }^{21}$ por isso seria razoável imaginar que a lei, ao fazer cessar ciclos de agressões intrafamiliares, gere também um efeito de segunda ordem para fazer diminuir os homicídios ocasionados por questões domésticas e de gênero.

A pesquisa Avaliando a Efetividade da Lei Maria da Penha ${ }^{22}$ apontou que a Lei $\mathrm{n}^{\mathrm{o}}$ 11.340/2006 fez diminuir, em cerca de 10\%, a taxa de homicídios contra mulheres praticados dentro das residências das vítimas. Muito embora esse dado signifique que milhares de mulheres deixaram de sofrer homicídios no Brasil, há que se avançar no que tange à sua efetividade.

A delegada, quando questionada sobre sua visão em relação aos motivos do número crescente de registros de crimes de violência doméstica, destacou que tem observado uma mudança de postura da mulher vítima de violência nos últimos anos. As mulheres alcançaram maior autonomia financeira, consciência dos seus direitos e, embora, em muitos casos, não desejem a separação do agressor, tendem a não se submeterem tão passivamente a situações de violência.

Não obstante estejam sempre em evidência as violências físicas, como lesão corporal circunscrita à lesão à integridade física da vítima, as demais formas de violências, como a psicológica e a moral começam também a ser identificadas pela vítima como atos violentos.

A pesquisadora Isadora Vier Machado, em sua tese de doutorado, destacou que:

No campo normativo-legal as violências psicológicas contra mulheres ganharam destaque na década de 1990, sua acolhida institucional aconteceu, no Brasil, um pouco antes da aprovação da Lei 11.340/06, em estruturas governamentais, ONG's, coletivos feministas, etc. Esteve, contudo, ligada à mobilização política que impulsionou a criação e implementação do diploma legal. Aos poucos, a categoria violência psicológica começa a aparecer nos registros brasileiros, ganhando projeção e sendo referida com frequência. ${ }^{23}$

Isso quer dizer que o reconhecimento da violência psicológica como forma de violência no campo normativo-legal é relativamente novo no Brasil, entretanto tem sido apontado como uma das principais formas de violência contra a mulher e, de modo crescente, tem 
sido reconhecido pela vítima, embora normalmente relacionado ao crime de ameaça ou insulto. Todavia, é importante destacar que o tipo penal da violência psicológica, previsto na Lei Maria da Penha (art. $\left.7^{\circ}, \mathrm{II}\right)$, é mais abrangente que um constrangimento proveniente de ameaça ou humilhação e é um tipo penal isolado, não precisando estar acompanhado de uma agressão física para que seja denunciado e punido. A Lei prevê que

Art. 7ำ São formas de violência doméstica e familiar contra a mulher, entre outras:

II - a violência psicológica, entendida como qualquer conduta que lhe cause dano emocional e diminuição da auto-estima ou que lhe prejudique e perturbe o pleno desenvolvimento ou que vise degradar ou controlar suas ações, comportamentos, crenças e decisões, mediante ameaça, constrangimento, humilhação, manipulação, isolamento, vigilância constante, perseguição contumaz, insulto, chantagem, ridicularização, exploração e limitação do direito de ir e vir ou qualquer outro meio que lhe cause prejuízo à saúde psicológica e à autodeterminação. ${ }^{24}$

Nesse sentido, é fundamental o papel da autoridade policial, do defensor público e do Ministério Público no reconhecimento da prática da violência psicológica, mesmo que a vítima, a princípio, não tenha consciência de que também é vítima desse tipo de violência.

Quanto aos motivos que levam a mulher a não chegar a registrar ocorrência contra o agressor, de acordo com Dias, ${ }^{25}$ vários são os motivos pelos quais a primeira agressão sofrida, geralmente, não é denunciada: a mulher pode vivenciar um conflito, por não desejar separar-se do companheiro ou não desejar a punição do agressor, pois apenas pretende que cessem as agressões. Além disso, de acordo com a mesma autora, frequentemente, as mulheres procuram justificar as atitudes do vitimador, por meio de argumentos, como o ciúme e a proteção, que acreditam ser demonstrações de amor. Atribuem ainda a fatores externos, como o estresse, decorrente principalmente do trabalho, das dificuldades financeiras e do cansaço os atos violentos contra elas praticados.

Também o álcool é um dos motivos alegados pela maioria das vítimas para explicar o comportamento agressivo de seus parceiros. Gregori ${ }^{26}$ argumenta que o álcool estimula esse tipo de comportamento dos homens, mas age apenas como um catalisador de uma vontade preexistente, havendo, portanto, uma intenção prévia ao consumo de álcool de ferir a integridade física da mulher. Além disso, o mesmo autor revela que, quando há o desejo de se separar do marido, essa ideia vem sempre acompanhada por sentimentos de culpa e vergonha pela situação em que vive, por medo, impotência e vulnerabilidade geral da vítima.

Os meios de comunicação têm trazido à mídia esse tipo de violência e as políticas públicas disponíveis para o amparo das vítimas o que, consequentemente, trouxe, de acordo com a Delegada da DEM de São Luís/MA, maior conscientização da mulher vítima de violência doméstica das mais diferentes classes sociais sobre seus direitos. Outro tipo de avanço, no âmbito da atuação policial, está relacionado ao uso da tecnologia no serviço de proteção da vítima, como o uso de tornozeleiras eletrônicas, "botão de socorro" etc. 
A realidade é que não existem oficiais de polícia disponíveis para realizar a vigilância de todas as mulheres que possuem deferimento de uma Medida Protetiva de Urgência a seu favor. De acordo com dados divulgados no G1 Maranhão, em julho de 2015, o Estado do Maranhão possui 1 (um) policial militar para 816 (oitocentos e dezesseis) habitantes ${ }^{27}$. Isso faz que recursos, como tornozeleiras eletrônicas para os agressores e o "botão de socorro" para a vítima sejam instrumentos fundamentais na eficácia da medida de urgência e proteção da mulher violentada.

A autoridade policial, de modo geral, é o órgão responsável por grande parte do primeiro atendimento que a mulher vítima de violência passa ao buscar ajuda e amparo do Estado, sendo essencial que esse atendimento seja realizado por pessoas com capacitação técnica e conhecimento transdisciplinar, de modo que não haja revitimização ou mesmo violência institucional contra essa mulher que vê, no Estado, o seu último ou único recurso. Além disso, a qualidade da instrução do inquérito policial é determinante para o oferecimento da denúncia e, consequentemente, para a condenação do réu.

\section{A VARA ESPECIALIZADA DE VIOLÊNCIA DOMÉSTICA E FAMILIAR CONTRA A MULHER: ATUAÇÃO NA CIDADE DE SÃO LUÍS}

Na cidade de São Luís/MA, há apenas uma Vara Especializada com atuação em crimes de violência doméstica contra a mulher. Considerando aspectos quantitativos, foi informado pela Vara que, em média, são realizadas 12 (doze) audiências por semana, não sendo especificados quais tipos de audiências estão incluídas nesse dado fornecido pela Vara (se relativas a MPUs, conciliação ou instrução processual, por exemplo); são despachados, em média, 30 (trinta) procedimentos cautelares por semanas, não havendo controle do tempo médio das movimentações destes. Destacou-se que são priorizados os despachos referentes aos procedimentos cautelares em detrimento das ações penais. A Vara não informou em relação à quantidade semanal ou mensal de decisões de mérito condenatórias e de absolvição.

Em relação às solicitações de medidas protetivas, pesquisa institucional do TJMA ${ }^{28}$ evidencia que $90 \%$ das medidas protetivas requeridas têm decisão concedendo-as à requerente. Desse percentual, $27,5 \%$ das medidas solicitadas têm por objetivo o distanciamento do representado em relação à representante; seguida da proibição de manter contato, 26,7\%, e proibição de frequentar determinados locais, como a residência e o local de trabalho da ofendida, 24\%. 89\% são de Sentença Inibitória e 11\% "outros", não sendo informado, no documento, a que esses "outros" se referem, de modo que não se pôde detalhar esse dado.

O procedimento cautelar é o mais simples, pois dispensa advogados e pode ser requerido por meio das Delegacias, Promotorias de Justiça, Casa da Mulher e até pela própria vítima. 
No entanto, não há análise de mérito nesse tipo de decisão, não havendo, portanto, condenação do réu e/ou efetivo enfrentamento da gravidade da violência denunciada.

Acontece que a mera medida protetiva não determina eficácia plena de proteção, embora possa inibir atos de violência. Portanto, é um equívoco entender que o grande número de decisões determinando medidas protetivas em favor da vítima é um indicador de efetiva proteção à mulher vítima de violência doméstica.

Não se está afirmando que a possibilidade da medida protetiva, trazida com a Lei Maria da Penha (Lei no 11.340/2006), não seja um importante instrumento processual que visa a inibir a prática de novos atos de violência contra a vítima. Entretanto, a realidade do Maranhão e de todo o Brasil é a carência de policiamento por habitante, sendo irracional pensar que sem fiscalização ou meios inibitórios eficientes uma mera decisão judicial de afastamento irá impedir o agressor de se aproximar ou até mesmo matar a vítima.

Dados disponibilizados pela $21^{\text {a }}$ Promotoria de Justiça Especializada na Defesa da Mulher da Capital do Maranhão apontam que durante o ano de 2014 foram oferecidas 152 (cento e cinquenta e duas) denúncias e 47 (quarenta e sete) alegações finais. Ainda no ano de 2014, dos $47^{29}$ processos em fase de instrução e julgamento, apenas 2 (dois) haviam transitado em julgado (ambos com sentença de absolvição); outros 13 (treze) possuíam sentença de absolvição, mas sem que tenham transitado em julgado e 12 (doze) possuíam sentença de condenação, mas sem transitar em julgado. Os 19 demais processos em fase de instrução e julgamento estavam sem sentença ou esperando as alegações finais da defesa e 1 (um) em segredo de justiça.

Esses dados demonstram que, mesmo sendo oferecidas 152 denúncias no ano de 2014, apenas 47 processos chegaram à fase de instrução e julgamento, ou seja, mais da metade, $69,1 \%$, dos processos com denúncias não chegaram à fase de julgamento. Mais grave ainda é perceber que dos 47 processos que chegaram à fase de instrução e julgamento, 20 (vinte), 42,5\%, não obtiveram sentença definitiva em 2014, e todas as 12 condenações não possuíram sentença transitada em julgado, o que significa que os réus, embora condenados, não tiveram as condenações executadas.

Foi evidenciado pela Vara Especializada em documentação do $\mathrm{TJMA}^{30}$ que a maioria de suas decisões são em virtude das determinações de Medidas Protetivas de Urgência, o que não é necessariamente um erro. Em contrapartida, é um completo equívoco pensar que indicações de medidas protetivas surtirão o efeito desejado quando o Poder Judiciário não tem sentenças de condenação transitadas em julgado, alimentando, senão a impunidade propriamente dita, a sensação de que agredir ou matar uma mulher não acarreta punição efetiva.

Este trabalho defende que a impunidade ou a sensação dela é um dos principais fatores que contribuem para os grandes índices de todas as formas de violência doméstica e feminicídio no país. Não existem estudos especializados ou profundos sobre a relação da impunidade e as taxas de violência doméstica, mas a análise de alguns dados nacionais apontados na 
pesquisa de Waiselfiss ${ }^{31}$ relacionando a população carcerária do Brasil e o número de casos registrados de violência contra a mulher corrobora com o entendimento de que existe impunidade para os crimes de violência doméstica em escala nacional no Brasil.

Nos últimos levantamentos realizados pelo Ministério da Justiça ${ }^{32}$ sobre a população carcerária ainda não consta a tipificação do crime de feminicídio, sancionado recentemente, que deverá começar a ser incorporado em futuros levantamentos. Ainda assim, foram registradas, no Grupo de Crimes contra a Pessoa, um total de 2.450 pessoas (2.430 do sexo masculino e 20 do feminino) acusadas de Violência Doméstica (Art. 129, § $9^{\circ}$, do Código Penal) ${ }^{33}$, que correspondem a 188.866 pessoas de quem o Departamento Penitenciário conseguiu completar as informações. ${ }^{34}$ De acordo com o mesmo relatório, a população prisional total era de 607.731 pessoas. Logo, conservando as proporções, pode-se chegar à estimativa de 7.912 o número de pessoas privadas de liberdade por Violência Doméstica (considerando o total de 607.731).

Entretanto, pelo Sistema de Informação de Agravos de Notificação (SINAN), é possível verificar que foram atendidas pelo SUS, em 2014, um total de 85,9 mil meninas e mulheres vítimas de violência exercida por pais, parceiros e ex-parceiros, filhos, irmãos: agressões de tal intensidade que demandaram atendimento médico. Estima-se que $80 \%$ dos atendimentos de saúde no País são realizados pelo SUS; assim, um total estimado de 107 mil meninas e mulheres devem ter sido atendidas em todo o sistema de saúde do País, vítimas de violências domésticas.

Considerando-se que, em 2014, havia, no Sistema Penitenciário Nacional, por motivo de Violência Doméstica, um número estimado de 7.912 pessoas privadas de liberdade, condenadas ou aguardando julgamento, tem-se que, no limite, apenas 7,4\% dos agressores domésticos, acusados de cometerem violências relativamente sérias contra vítimas que demandaram atendimento no sistema de saúde do País, foram condenados ou estão esperando julgamento - o que não significa que serão condenados.

Como a pena prevista no Art. 129, § 9. ${ }^{\circ}$, do Código Penal é de 3 meses a 3 anos, pode-se supor um índice de condenação ainda menor que 7,4\%. Evidenciando- se, mais uma vez, o império da impunidade no país para esse tipo de crime.

\section{1 ANÁLISE DOS DADOS DOS PROCESSOS DE VIOLÊNCIA DOMÉSTICA QUE TRAMITARAM NA VARA ESPECIALIZADA DE VIOLÊNCIA DOMÉSTICA E FA- MILIAR CONTRA A MULHER DA COMARCA DE SÃO LUÍS DE ACORDO COM LEVANTAMENTO DO ANO DE 2014}

Em relatório de pesquisa institucional referente aos casos denunciados na Vara Especializada de Violência Doméstica e Familiar contra a Mulher, na comarca de São Luís, no ano de 2014, foram compilados dados estatísticos referentes às vítimas, aos réus, aos atos de violência, às denúncias e às medidas protetivas de urgência. A pesquisa, realizada por uma equipe multidisciplinar, analisou $34 \%$ dos processos em tramitação naquela unidade, 
no período de janeiro a abril de 2014, relativos somente a casos de medidas protetivas de urgência, no total de 414 ações judiciais. Em 2015, tramitavam, na Vara Especializada, cerca de cinco mil processos, dos quais 473 foram distribuídos somente em 2015. ${ }^{35}$

Quanto às vítimas, de acordo com a pesquisa institucional citada, 36\% das mulheres em situação de violência, representantes em processos de Medidas Protetivas de Urgência-MPU's na Vara Especializada de Violência Doméstica e Familiar contra a Mulher- VEVDFM, no ano de 2014, tinham entre 26 e 34 anos de idade; 60\% eram solteiras, 20\%, casadas e 15\% declararam estar em um relacionamento de união estável. Em apenas 17,2 por cento dos processos pesquisados, foi possível identificar o grau de instrução das vítimas, em que 8\% das vítimas (dos 17,2\%) possuíam Ensino Superior completo, seguido por 4,8\% com Ensino Médio completo. Quanto ao exercício de atividade remunerada, 52\% das mulheres afirmaram que exercem algum tipo de atividade remunerada nos processos em que foi possível extrair tal informação. $\mathrm{O}$ item referente à renda não conseguiu capturar tal informação de forma válida, uma vez que, em 96\% dos autos, não consta essa informação; 24,2\% eram donas de casa, enquanto 11,1\% eram empregadas domésticas e 5,1\% comerciárias. Os bairros de moradia mais identificados foram: Coroadinho, Anjo da Guarda e Turu; 55\% das mulheres afirmaram ter filhos com o requerido, e 91\% das vítimas do estudo são maranhenses. ${ }^{36}$

Da análise dos dados descritos acima, destaque-se que a Vara em questão exclui de seu escopo de proteção mulheres meninas e idosas, mulheres homossexuais e mulheres transgêneras, não havendo qualquer instrução processual que inclua a proteção a essas categorias de mulheres na Vara Especializada até março de 2016. Além disso, esses dados apresentados no relatório fornecido pelo TJMA ${ }^{37}$ evidenciam a precariedade dos inquéritos policiais, com dados imprecisos, escassos de informações mínimas sobre as vítimas e sobre os agressores.

De acordo com Rabello e C. Júnior, ${ }^{38}$ o fator renda pode interferir diretamente para que a violência aconteça, assim como o nível de escolaridade.

Vale destacar que, embora alguns autores relacionem a pobreza à violência doméstica contra a mulher, ela também está inserida em classes médias e altas. Adeodato et al. ${ }^{39}$ relatam que famílias de maior poder aquisitivo dispõem de recursos políticos e econômicos para, em muitos casos, ocultar a violência doméstica, surgindo, então, uma alteração nos dados de violência registrados.

Quanto aos dados referentes aos réus, a faixa etária com maior incidência é entre 26 a 34 anos (29,5\% do total); 61\% são solteiros, 20\% são casados e 13\% vivem em união estável; em relação à escolaridade, não foi possível obter dado significativo, visto que, em 89,4\% dos processos, não constava essa informação. Em 64,5\% dos processos, foi identificado o exercício de alguma atividade remunerada pelo representado. 
Alguns autores, como Giffin ${ }^{40}$ relacionam a violência com o desemprego, já que este pode, em alguns casos, desestabilizar a identidade masculina, o que faz que o homem transfira a frustração com o desemprego, em forma de violência, para as suas parceiras.

Em mais de $60 \%$ dos processos, não havia informação sobre o uso de bebida alcoólica, no entanto, em 33\%, foi apontado o uso abusivo de álcool como um fator eliciador da violência denunciada. Quanto ao uso de drogas, em 19\%, foi apontada essa problemática. Rabello e Júnior $^{41}$ destacam que a violência doméstica contra a mulher ocorre, muitas vezes, devido ao alto consumo de álcool pelos agressores. Além disso, o referido autor aponta que estudos demonstram que o álcool parece ser a droga mais nociva ao funcionamento familiar, pois, por ser aceito socialmente, passa a ser consumido em grandes quantidades, principalmente pelos homens. Importante destacar mais uma vez que o ato de violência não se justifica apenas pelo consumo do álcool, ele é apenas um catalizador da intenção de agressão.

Um total de 40,1\% dos agressores eram os ex-companheiros das representantes, enquanto 17,1\% eram companheiros e 12,3\%, esposos. Quanto aos bairros de maior incidência, destacaram-se os Bairros Coroadinho (com 6,3\%), seguido do Anjo da Guarda (4,1\%) e São Francisco/Ilhinha (2,9\%).

A análise que se faz do relatório realizado e disponibilizado pela Vara Especializada é de que se trata de um documento meramente quantitativo de exposição de dados, restringindo-se a perfis sociais de vítimas e agressores, o que não ajuda a compreender o fenômeno da violência doméstica contra a mulher, além de não possibilitar reflexões em relação à efetividade da Vara no processamento e julgamento das lides em questão.

Em relação aos atos de violência praticados e evidenciados no documento do TJMA, ${ }^{42}$ 34,4\% são de prática de violência psicológica; 29,2\% de violência moral/injúria; 24\% de prática de violência física. Em $71 \%$ dos casos, a violência foi praticada dentro de casa, e o inconformismo com o fim do relacionamento apareceu como o principal motivador para a prática da violência, pontuando $26,3 \%$, seguido de problemas decorrentes do uso abusivo e dependência de álcool e outras drogas, com 18,1\% e do ciúme, com 13,3\% do total. O maior percentual, entretanto, foi alcançando por "outros motivos", com 34,9\%, em que mais uma vez não foi possível obter informações do que o relatório incluiu dentro da classificação "outros".

O estudo realizado indica um dado interessante em relação ao percentual referente às violências psicológica e moral. $\bigcirc$ maior percentual desses tipos de violências demonstra maior reconhecimento dessas modalidades de crime que até a Lei Maria da Penha não eram tipificadas com propriedade como formas de violências contra a mulher. Esses dados demonstram também um avanço nesse sentido, uma vez que as violências psicológica e moral têm efeitos devastadores sobre a mulher, muitas vezes mais intensos e reincidentes que a violência física. 
No que se refere à origem dos processos com pedidos de medidas protetivas, $69 \%$ são originárias da Delegacia Especial da Mulher; 21\%, de outras instituições; 10\%, da Casa de Referência da Mulher; 7\%, Defensoria Pública; e 6\% solicitadas diretamente na própria Vara Especial da Mulher, ${ }^{43}$ entretanto sem informações se foi a vítima que pessoalmente realizou o pedido de medida protetiva na Vara.

Esse dado mais uma vez corrobora com o que fora defendido no capítulo anterior a respeito da importância da qualidade e do trabalho da autoridade policial, por ser ela a maior responsável pelo primeiro atendimento à mulher vítima de violência doméstica e demais formas de violência de gênero.

Não se pretende com a discussão da síntese desses dados esgotar a análise referente a eles. Conforme bem elucidado na conclusão da referida pesquisa institucional do TJMA: ${ }^{44}$

Os resultados desta pesquisa confirmam algumas informações já registradas em estudos anteriores e apresentam um pouco da realidade da cidade de São Luís, no intuito de contribuir, conforme anteriormente mencionado, não só para o conhecimento da realidade em que se encontra a mulher que sofre de violência de gênero. Pretende-se, sim, contribuir para uma atuação mais responsável e eficaz, a partir do conhecimento dessa realidade, por parte desta Vara Especializada de Violência Doméstica e Familiar, junto com as demais instituições da rede de atenção à mulher em situação de violência. Verifica-se quão necessário se faz intensificar as ações de alcance social, também de caráter preventivo, nos mais diversos espaços sociais. Fundamental também é a articulação do Poder Judiciário com outras áreas de atuação do poder governamental, a exemplo das políticas púbicas de Segurança, Saúde e Educação.

Para o relatório realizado pelo TJMA, ${ }^{45}$ representado pela Vara Especializada de Violência Doméstica e Familiar Contra a Mulher, um dado positivo e resultado da melhor atuação das instituições que compõem a Rede de Atendimento à Mulher, em São Luís, é o crescimento do número de representações criminais em 2014. Inferiu-se que esse crescimento pode também ser consequência do investimento dessas instituições em ações preventivas e informativas sobre a Lei 11.340/2006 ${ }^{46}$ e principalmente demonstra que a mulher ludovicente tem se tornado menos tolerante à violência doméstica.

Por fim, cabe a fala de Júlio Jacobo Waiselfisz em seu estudo Mapa da Violência 2015: Homicídio de mulheres no Brasil:

Recentemente, Raúl Eugenio Zaffaroni, Ministro da Suprema Corte Argentina e diretor do Departamento de Direito Penal e Criminologia na Universidade de Buenos Aires, colocava em uma entrevista: "Cada país tem o número de presos que decide politicamente ter". Por minha conta e risco, complementaria a afirmação do ilustre professor: "Cada país tem o número de feminicídios que decide politicamente ter, assim como o número de condenações por essa agressão".47 


\section{CONSIDERAÇÕES FINAIS}

A luta pelo fim da violência contra a mulher no Brasil teve como marco a Lei n ${ }^{\circ} .11 .340$, de 7 de agosto de 2006, conhecida por Lei Maria da Penha. Esta foi fruto de fatores conjunturais, como pressões internacionais pela defesa dos direitos humanos e erradicação da violência contra a mulher, de várias lutas das mulheres para que a violência de gênero fosse vista como uma questão de políticas públicas e afirmação da necessidade de o Estado intervir de forma direta por meio de leis e políticas públicas que erradicassem esse tipo de violência, que detém as suas bases numa lógica patriarcal de poder e dominação masculina de um lado e subordinação e opressão da mulher de outro. Contudo, as leis não bastam. É preciso acionar um leque de políticas públicas que garantam e possibilitem a efetivação e disseminação dessa nova lógica social baseada na ideia de que a violência contra a mulher viola os direitos humanos e é crime.

Nesse sentido, é de fundamental importância analisar o trabalho realizado e as dificuldades enfrentadas pelos órgãos que atuam diretamente junto à mulher vítima de violência desde o primeiro contato com a autoridade policial responsável pela instrução do inquérito policial até a última instância, representada pelo Poder Judiciário, responsável pela instrução do processo penal e detentor do poder de punir.

Evidenciou-se que a atuação em crimes de violência doméstica exige uma qualificação técnica específica, uma vez que demanda uma atuação transdisciplinar daqueles que atuam frente ao fenômeno aludido. A complexidade do fenômeno em questão inclui o fato de a vítima e o agressor estarem unidos por elos afetivos pretéritos ou presentes, de a violência ser cíclica, definindo uma vulnerabilidade específica da vítima, em especial, dependência financeira e emocional, além de conflitos familiares sedimentados face à violência sofrida. Daí a importância de um trabalho cada vez mais articulado e especializado por parte dos profissionais que atuam diretamente junto à vítima, tendo em vista a necessidade de toda uma rede que envolve procedimento criminal, assistência psicológica, social e jurídica, além de proteção física e psicológica da mulher violentada.

A DEM, de São Luís/MA, informou que, no ano de 2014, foram iniciados cerca de 900 (novecentos) inquéritos policiais para investigar possíveis casos de violência contra a mulher, entretanto a $2^{\text {a }}$ Promotoria de Justiça Especializada de Defesa da Mulher aponta que, de acordo com seu controle interno, só foram oferecidas 152 denúncias no ano de 2014 por aquela Promotoria de Justiça. É importante destacar que só existem duas Promotorias de Justiças Especializadas de Defesa da Mulher na cidade de São Luís e, em teoria, por uma ou outra passaram o total dos 900 inquéritos policiais iniciados na DEM. Isso quer dizer que, em média, 450 inquéritos deveriam ter passados por cada uma das Promotorias de Justiça Especializadas, concluindo-se que 152 denúncias oferecidas se torna um número inexpressivo ao considerar a média de 450 inquéritos.

Ademais, apenas 47 processos (do total das 152 denúncias oferecidas) chegaram à fase de instrução e julgamento, ou seja, mais da metade, $69,1 \%$, dos processos com denúncias não 
chegaram à fase de julgamento. $\mathrm{O}$ que se torna ainda mais grave é perceber que desses 47 processos que chegaram à fase de instrução e julgamento 20 (vinte), 42,5\%, não obtiveram sentença definitiva em 2014, e das 12 sentenças de condenações, em 2014, que existiram em processos distribuídos para a $2^{\text {a }}$ Promotoria de Justiça Especializada de Defesa da Mulher nenhum possuía sentença transitada em julgado. Isso significa dizer que os réus, embora condenados, não tiveram as condenações executadas, evidenciando-se a impunidade pelo próprio sistema de justiça.

Embora o crescimento do número de representações criminais (37\%, em 2014) demonstre que a mulher de São Luís esteja menos tolerante em relação à violência doméstica, esse dado isolado não possui valor caso não haja efetiva punição do agressor por parte do Poder Judiciário. Nesse sentido, entende-se que a Vara de Violência Doméstica e Familiar Contra a Mulher da Cidade de São Luís/MA precisa repensar a sua atuação diante do pequeno número de processos que possuem decisões de mérito e condenações transitadas em julgado. Destaca-se que apenas focar em concessão de medidas protetivas de urgência é um equívoco, caso não haja um esforço ainda maior para instrução e julgamento dos processos, uma vez que sem condenação efetiva do réu não há garantia de proteção, tampouco justiça.

Apesar da existência de avanços nas políticas sociais que garantem os direitos das mulheres, ainda há muito a ser feito diante dos números crescentes de casos de violência doméstica, o que nos faz indagar se todas as políticas sociais estão sendo praticadas de forma efetiva no combate a esse tipo de violência.

A rede de enfrentamento à violência contra a mulher, se bem estruturada, constitui uma política pública de imensurável relevância, tendo em vista que o esforço se direciona a minimizar um problema que assume contornos cada vez mais graves no mundo e no Brasil, constituindo grave violação de direitos humanos. Nesse aspecto, o eficiente trabalho da autoridade policial articulado com instituições do sistema de justiça comprometidas e que assumam a sua responsabilidade diante da gravidade da violência contra a mulher podem alcançar os reais objetivos da Lei Maria da Penha. Uma proteção legal, por melhor que seja, não gera efeitos quando está apenas no papel; é necessário que toda a sociedade tome consciência de que a violência contra a mulher não é mais admitida no Brasil e que a impunidade não encontra mais espaço.

Para que o aumento dos casos de violência contra a mulher deixe de ser uma realidade, necessita-se de um olhar mais amplo, que ultrapasse atuações isoladas das Delegacias Especiais da Mulher, Promotorias Estaduais e Varas Especializadas, também é necessário que o planejamento estratégico da rede seja pressuposto pelo envolvimento dos órgãos federais, estaduais e municipais na tarefa de concretizar a proteção da vítima de violência que recorre à proteção do Estado. Assim, deve haver um aperfeiçoamento constante, seja por meio da discussão conjunta dos órgãos acerca das dificuldades enfrentadas e alternativas viáveis, seja por meio da abertura das decisões institucionais à sociedade civil organizada, que também é parte integrante da rede, além do diálogo com a própria mulher em situação de violência, sujeito central de toda a atenção estatal e destinatária dos esforços envolvidos na rede. 
Ressalta-se, neste trabalho, o papel fundamental das instituições acadêmicas maranhenses no sentido de produzir estudos e visibilizar dados voltados para o tema, de modo a analisar como tem sido realizado o enfrentamento da violência contra a mulher e quais os principais pontos de dificuldades enfrentados pelas instituições do sistema de justiça que atuam diretamente com a mulher vítima de violência. Refletir criticamente sobre as fragilidades no atendimento prestado é fundamental para a implementação de melhores ações.

Por fim, destaca-se, mais uma vez, que a superação do fenômeno da violência doméstica ultrapassa ações isoladas da autoridade policial e do Poder Judiciário. A política de enfrentamento dessa violência engloba a segurança pública, educação, trabalho e renda, habitação e todas as secretarias e os ministérios no âmbito federal, estadual e municipal trabalhando em conjunto para enfrentar esse fenômeno. Nesse ano de 2016, a Lei Maria da Penha completa dez anos, e o momento é oportuno para maiores ações de combate e prevenção da violência doméstica, uma vez que discussões sobre o tema têm estado na pauta de diversas esferas governamentais.

\section{REFERÊNCIAS}

ADEODATO, V. G. et al. Qualidade de vida e depressão em mulheres vítimas de seus parceiros. Revista Saúde Pública, São Paulo, v. 39, n. 1, p. 108-113, 2005.

BRASIL. Lei $n^{0} 10.683$, de 28 de maio de 2003. Dispõe sobre a organização da Presidência da República e dos Ministérios, e dá outras providências. Diário Oficial da União, Brasília, DF, 2003.

. Lei $n^{0} 11.340$, de 7 de agosto de 2006. Cria mecanismos para coibir a violência doméstica e familiar contra a mulher. Diário Oficial da União, Brasília, DF, 2006.

. Ministério da Saúde. Violência intrafamiliar: orientações para a prática do serviço. Caderno de atenção básica, Brasília, n. 8, p. 28, 2003.

- Ministério da Justiça. INFOPEN. Levantamento nacional de informações penitenciárias: junho de 2014. Brasília: Departamento Penitenciário Nacional/MJ, 2015.

. Presidência da República. Secretaria de Políticas para Mulheres. Política nacional de enfrentamento à violência contra as mulheres. Brasília: Ideal, 2011.

. Presidência da República. Secretaria de Políticas para Mulheres. Pacto nacional pelo enfrentamento à violência contra mulheres. Brasília: Ideal, 2011.

CALAZANS, M.; CORTES, I. O processo de criação, aprovação e implementação da Lei Maria da Penha. In: CAMPOS, C. H. (Org.). Lei Maria da Penha comentada em uma perspectiva jurídico-feminista. Rio de Janeiro: Editora Lumem Juris, 2011. 
CERQUEIRA, D. R. C.; COELHO, D. S. C. Mapa das armas de fogo nas microrregiões brasileiras. In: BOUERI, Rogério; COSTA, Marco Aurélio. Brasil em desenvolvimento 2013: estado, planejamento e políticas públicas. Brasília: Ipea, 2013. v. 3. p. 899-913. Disponível em: <http://www.ipea.gov.br/portal/images/stories/PDFs/livros/livros/livro_brasil _desenvolvimento2013_vol03.pdf>. Acesso em: 20 dez. 2015.

CERQUEIRA, Daniel et al. Avaliando a Efetividade da Lei Maria da Penha. Rio de Janeiro: IPEA, 2015. Disponível em: <http://www.ipea.gov.br/portal/images/stories/PDFs/TDs/ td_2048.pdf>. Acesso em: $20 \mathrm{dez} .2015$.

DIAS, Maria Berenice. A Lei Maria da Penha na justiça: a efetividade da Lei 11.340/2006 de combate à violência doméstica e familiar contra a mulher. 3. ed. São Paulo: Revista dos Tribunais, 2012.

CARRAMILO, Clarissa. Maranhão tem a pior taxa do país de policial militar por habitantes. 2015. Disponívelem: <http://g1.globo.com/ma/maranhao/noticia/2015/07/maranhao-tem-pior-taxa-do-pais-de-policial-militar-por-habitantes.html>. Acesso em: 20 ago. 2015.

GIFFIN, K. Pobreza, desigualdade e equidade em saúde: considerações a partir de uma perspectiva de gênero transversal. Caderno de Saúde Pública, Rio de Janeiro, v. 18, p. 103-112, 2002.

GREGORI, Maria Filomena. Cenas e queixas: um estudo sobre mulheres, relações violentas e a prática feminista. Rio de Janeiro: Paz e Terra, 1992.

MACHADO, Isadora Vier. Da dor no corpo à dor na alma: uma leitura do conceito de violência psicológica da Lei Maria da Penha. 2013. 282 f. Tese (Doutorado em Ciências Humanas) - Universidade Federal de Santa Cataria, Florianópolis, 2013.

MENEZES, Ana Luiza Teixeira. Mulheres: fruto de dominação e fruta para libertação! In: STREY, Marlene Neves et al. (Org.). Construções e perspectivas em gênero. São Leopoldo: Unisinos, 2000. p. 125-134.

RABELLO, P. M.; CALDAS JÚNIOR, A. F. Violência contra a mulher, coesão familiar e drogas. Rev. Saúde Pública, v. 41, n. 6, p. 970-978, 2007.

RÊGO, Nelson Melo de Moraes (Coord.). Violência doméstica contra a mulher: dados estatísticos da vara especializada da comarca de São Luis. São Luís: Vara especial de violência doméstica e familiar contra a mulher, 2015. Disponível em: < http://gerenciador.tjma.jus.br/ app/webroot/files/publicacao/407035/dados_estatosticos_da_vara_especializada_da_comarca_de_soo_luos_-_ano_2015_23102015_0848.pdf>. Acesso em: 25 jul. 2015.

WAISELFISZ, Julio Jacobo. Mapa da violência 2015: homicídio de mulheres no Brasil. Rio de Janeiro: FLACSO Brasil, 2015. Disponível em: <www.mapadaviolencia.org.br>. Acesso em: 20 dez. 2015. 
1 Esta definição foi realizada no Caderno de atenção básica n ${ }^{\circ} .8$ elaborado pela OMS. BRASIL. Ministério da Saúde. Violência intrafamiliar: orientações para a prática do serviço. Caderno de atenção básica, Brasília, n. 8, p. 15, 2003.

2 WAISELFISZ, Julio Jacobo. Mapa da violência 2015: homicídio de mulheres no Brasil. Rio de Janeiro: Flacso Brasil, 2015. Disponível em: <www.mapadaviolencia.org.br>. Acesso em: 20 dez. 2015.

3 CERQUEIRA, D. R. C.; COELHO, D. S. C. Mapa das armas de fogo nas microrregiões brasileiras. In: BOUERI, Rogério; COSTA, Marco Aurélio. Brasil em desenvolvimento 2013: estado, planejamento e políticas públicas. Brasília: Ipea, 2013. v. 3. p. 899-913. Disponível em: <http://www.ipea.gov.br/portal/ images/stories/PDFs/livros/livros/livro_brasil_desenvolvimento2013_vol03.pdf>. Acesso em: 20 dez. 2015.

4 BRASIL. Presidência da República. Secretaria de Políticas para Mulheres. Política nacional de enfrentamento à violência contra as mulheres. Brasília: Ideal, 2011.

5 Para melhor compreensão da legislação citada, ler: BRASIL. Lei 10.683/03, de 28 de maio de 2003. Dispõe sobre a organização da Presidência da República e dos Ministérios, e dá outras providências. Diário Oficial da União, Brasília, DF, 2003.

6 BRASIL. Presidência da República. Secretaria de Políticas para Mulheres. Política nacional de enfrentamento à violência contra as mulheres. Brasília: Ideal, 2011.

7 Este conceito foi retirado da leitura de: BRASIL. Presidência da República. Secretaria de Políticas para Mulheres. Política nacional de enfrentamento à violência contra as mulheres. Brasília: Ideal, 2011.

8 Para melhor compreensão de toda a estrutura da Lei n. 11.340/2006, sugere-se a leitura do texto legislativo completo: BRASIL. Lei n. 11.340, de 7 de agosto de 2006. Cria mecanismos para coibir a violência doméstica e familiar contra a mulher. Diário Oficial da União, Brasília, DF, 2006.

9 CALAZANS, M.; CORTES, I. O processo de criação, aprovação e implementação da Lei Maria da Penha. In: CAMPOS, C. H. (Org.). Lei Maria da Penha comentada em uma perspectiva jurídico-feminista. Rio de Janeiro: Lumem Juris, 2011.

10 WAISELFISZ, Julio Jacobo. Mapa da violência 2015: homicídio de mulheres no Brasil. Rio de Janeiro: FLACSO Brasil, 2015. Disponível em: <www.mapadaviolencia.org.br>. Acesso em: 20 dez. 2015.

11 WAISELFISZ, Julio Jacobo. Mapa da violência 2015: homicídio de mulheres no Brasil. Rio de Janeiro: FLACSO Brasil, 2015. Disponível em: <www.mapadaviolencia.org.br>. Acesso em: 20 dez. 2015.

12 BRASIL. Presidência da República. Secretaria de Políticas para Mulheres. Pacto nacional pelo enfrentamento à violência contra mulheres. Brasília: Ideal, 2011.

13 BRASIL. Lei $\mathrm{n}^{\circ} 11.340$, de 7 de agosto de 2006. Cria mecanismos para coibir a violência doméstica e familiar contra a mulher. Diário Oficial da União, Brasília, DF, 2006. Disponível em: <http://www.planalto.gov. br/ccivil_03/_ato2004-2006/2006/lei/111340.htm>.

14 BRASIL. Lei $\mathrm{n}^{\circ}$ 11.340, de 7 de agosto de 2006. Cria mecanismos para coibir a violência doméstica e familiar contra a mulher. Diário Oficial da União, Brasília, DF, 2006. Disponível em: <http://www.planalto.gov. br/ccivil_03/_ato2004-2006/2006/lei/111340.htm>.

15 BRASIL. Lei $\mathrm{n}^{\circ}$ 11.340, de 7 de agosto de 2006. Cria mecanismos para coibir a violência doméstica e familiar contra a mulher. Diário Oficial da União, Brasília, DF, 2006. Disponível em: <http://www.planalto.gov. br/ccivil_03/_ato2004-2006/2006/lei/111340.htm>.

16 Como não foi informado o número exato de servidores naquela DEM, essa análise fica prejudicada.

17 BRASIL. Ministério da Saúde. Violência intrafamiliar: orientações para a prática do serviço. Caderno de atenção básica, Brasília, n. 8, p. 28, 2003.

18 MENEZES, Ana Luiza Teixeira. Mulheres: fruto de dominação e fruta para libertação! In: STREY, Marlene Neves et al. (Org.). Construções e perspectivas em gênero. São Leopoldo: Unisinos, 2000. p. 125-134.

19 REGGO, Nelson Melo de Moraes (Coord.). Violência doméstica contra a mulher: dados estatísticos da vara especializada da comarca de São Luis. São Luís: Vara especial de violência doméstica e familiar contra a mulher, 2015. Disponível em: <http://gerenciador.tjma.jus.br/app/webroot/files/publicacao/407035/ dados_estatosticos_da_vara_especializada_da_comarca_de_soo_luos_-_ano_2015_23102015_0848.pdf > . Acesso em: 25 jul. 2015.

20 WAISELFISZ, Julio Jacobo. Mapa da violência 2015: homicídio de mulheres no Brasil. Rio de Janeiro: FLACSO Brasil, 2015. Disponível em: <www.mapadaviolencia.org.br>. Acesso em: 20 dez. 2015. 
21 CERQUEIRA, Daniel et al. Avaliando a Efetividade da Lei Maria da Penha. Rio de Janeiro: IPEA, 2015. Disponível em: <http://www.ipea.gov.br/portal/images/stories/PDFs/TDs/td_2048.pdf>. Acesso em: 20 dez. 2015.

22 CERQUEIRA, Daniel et al. Avaliando a Efetividade da Lei Maria da Penha. Rio de Janeiro: IPEA, 2015. Disponível em: < http://www.ipea.gov.br/portal/images/stories/PDFs/TDs/td_2048.pdf>. Acesso em: 20 dez. 2015.

23 MACHADO, Isadora Vier. Da dor no corpo à dor na alma: uma leitura do conceito de violência psicológica da Lei Maria da Penha. 2013. 282 f. Tese (Doutorado em Ciências Humanas) - Universidade Federal de Santa Cataria, Florianópolis, 2013. p. 148.

24 BRASIL. Lei $n^{\circ} 11.340$, de 7 de agosto de 2006. Cria mecanismos para coibir a violência doméstica e familiar contra a mulher. Diário Oficial da União, Brasília, DF, 2006. Disponível em: <http://www.planalto.gov. br/ccivil_03/_ato2004-2006/2006/lei/111340.htm>.

25 DIAS, Maria Berenice. A Lei Maria da Penha na justiça: a efetividade da Lei 11.340/2006 de combate à violência doméstica e familiar contra a mulher. 3. ed. São Paulo: Revista dos Tribunais, 2012.

26 GREGORI, Maria Filomena. Cenas e queixas: um estudo sobre mulheres, relações violentas e a prática feminista. Rio de Janeiro: Paz e Terra, 1992.

27 Dados obtidos em notícia divulgada em: G1. CARRAMILO, Clarissa. Maranhão tem a pior taxa do país de policial militar por habitantes. 2015. Disponível em: <http://g1.globo.com/ma/maranhao/noticia/2015/07/ maranhao-tem-pior-taxa-do-pais-de-policial-militar-por-habitantes.html>. Acesso em: 20 ago. 2015.

28 REGG, Nelson Melo de Moraes (Coord.). Violência doméstica contra a mulher: dados estatísticos da vara especializada da comarca de São Luis. São Luís: Vara especial de violência doméstica e familiar contra a mulher, 2015. Disponível em: <http://gerenciador.tjma.jus.br/app/webroot/files/publicacao/407035/dados_estatosticos_da_vara_especializada_da_comarca_de_soo_luos_-_ano_2015_23102015_0848.pdf>. Acesso em: 25 jul. 2015.

29 Dados do controle privado realizado pela $21^{\text {a }}$ Promotoria de Justiça Especializada da Mulher da Capital do Maranhão atualizados até dezembro de 2014.

30 RÊGO, Nelson Melo de Moraes (Coord.). Violência doméstica contra a mulher: dados estatísticos da vara especializada da comarca de São Luis. São Luís: Vara especial de violência doméstica e familiar contra a mulher, 2015. Disponível em: <http://gerenciador.tjma.jus.br/app/webroot/files/publicacao/407035/ dados_estatosticos_da_vara_especializada_da_comarca_de_soo_luos_-_ano_2015_23102015_0848.pdf > . Acesso em: 25 jul. 2015.

31 WAISELFISZ, Julio Jacobo. Mapa da violência 2015: homicídio de mulheres no Brasil. Rio de Janeiro: FLACSO Brasil, 2015. Disponível em: <www.mapadaviolencia.org.br>. Acesso em: 20 dez. 2015.

32 BRASIL. Ministério da Justiça. INFOPEN. Levantamento nacional de informações penitenciárias: junho de 2014. Brasília: Departamento Penitenciário Nacional/MJ, 2015.

33 O Art. 129, § 9. ${ }^{\circ}$, do Código Penal estabelece como Violência Doméstica a lesão corporal qualificada pela proximidade do vínculo familiar entre a vítima e o agressor: qualquer parente em linha reta - ascendentes ou descendentes, colaterais até o segundo grau - irmãos e cônjuge ou companheiro.

34 Segundo Waiselfisz (2015), duas ressalvas têm de ser, ainda, colocadas na análise específica desses dados: 1) essas são as tipificações penais dos crimes: a mesma pessoa pode ser acusada de mais de um crime, portanto o número de crimes tipificados pode ser igual ou superior ao número de pessoas em regime de privação da liberdade; 2) os 2.450 crimes correspondem a 188.866 pessoas de quem o Departamento Penitenciário Nacional (DEPEN) conseguiu completar as informações.

35 RÊGO, Nelson Melo de Moraes (Coord.). Violência doméstica contra a mulher: dados estatísticos da vara especializada da comarca de São Luis. São Luís: Vara especial de violência doméstica e familiar contra a mulher, 2015. Disponível em: < http://gerenciador.tjma.jus.br/app/webroot/files/publicacao/407035/ dados_estatosticos_da_vara_especializada_da_comarca_de_soo_luos_-_ano_2015_23102015_0848.pdf >. Acesso em: 25 jul. 2015.

36 RÊGO, Nelson Melo de Moraes (Coord.). Violência doméstica contra a mulher: dados estatísticos da vara especializada da comarca de São Luis. São Luís: Vara especial de violência doméstica e familiar contra a mulher, 2015. Disponível em: <http://gerenciador.tjma.jus.br/app/webroot/files/publicacao/407035/ dados_estatosticos_da_vara_especializada_da_comarca_de_soo_luos_-_ano_2015_23102015_0848.pdf > . Acesso em: 25 jul. 2015. 
37 RÊGO, Nelson Melo de Moraes (Coord.). Violência doméstica contra a mulher: dados estatísticos da vara especializada da comarca de São Luis. São Luís: Vara especial de violência doméstica e familiar contra a mulher, 2015. Disponível em: <http:/gerenciador.tjma.jus.br/app/webroot/files/publicacao/407035/ dados_estatosticos_da_vara_especializada_da_comarca_de_soo_luos_-_ano_2015_23102015_0848.pdf>. Acesso em: 25 jul. 2015.

38 RABELLO, P. M.; CALDAS JÚNIOR, A. F. Violência contra a mulher, coesão familiar e drogas. Rev. Saúde Pública, v. 41, n. 6, p. 970-978, 2007.

39 ADEODATO, V. G. et al. Qualidade de vida e depressão em mulheres vítimas de seus parceiros. Revista Saúde Pública, São Paulo, v. 39, n. 1, p. 108-113, 2005.

40 GIFFIN, K. Pobreza, desigualdade e equidade em saúde: considerações a partir de uma perspectiva de gênero transversal. Caderno de Saúde Pública, Rio de Janeiro, v. 18, p. 103-112, 2002.

41 RABELLO, P. M.; CALDAS JÚNIOR, A. F. Violência contra a mulher, coesão familiar e drogas. Rev. Saúde Pública, v. 41, n. 6, p. 970-978, 2007.

42 REGO, Nelson Melo de Moraes (Coord.). Violência doméstica contra a mulher: dados estatísticos da vara especializada da comarca de São Luis. São Luís: Vara especial de violência doméstica e familiar contra a mulher, 2015. Disponível em: <http:/gerenciador.tjma.jus.br/app/webroot/files/publicacao/407035/ dados_estatosticos_da_vara_especializada_da_comarca_de_soo_luos_-_ano_2015_23102015_0848.pdf > . Acesso em: 25 jul. 2015.

43 RÊGO, Nelson Melo de Moraes (Coord.). Violência doméstica contra a mulher: dados estatísticos da vara especializada da comarca de São Luis. São Luís: Vara especial de violência doméstica e familiar contra a mulher, 2015. Disponível em: <http://gerenciador.tjma.jus.br/app/webroot/files/publicacao/407035/ dados_estatosticos_da_vara_especializada_da_comarca_de_soo_luos_-_ano_2015_23102015_0848.pdf > . Acesso em: 25 jul. 2015.

44 RÊGO, Nelson Melo de Moraes (Coord.). Violência doméstica contra a mulher: dados estatísticos da vara especializada da comarca de São Luis. São Luís: Vara especial de violência doméstica e familiar contra a mulher, 2015. Disponível em: <http:/gerenciador.tjma.jus.br/app/webroot/files/publicacao/407035/ dados_estatosticos_da_vara_especializada_da_comarca_de_soo_luos_-_ano_2015_23102015_0848.pdf > . Acesso em: 25 jul. 2015.

45 RÊGO, Nelson Melo de Moraes (Coord.). Violência doméstica contra a mulher: dados estatísticos da vara especializada da comarca de São Luis. São Luís: Vara especial de violência doméstica e familiar contra a mulher, 2015. Disponível em: <http:/gerenciador.tjma.jus.br/app/webroot/files/publicacao/407035/ dados_estatosticos_da_vara_especializada_da_comarca_de_soo_luos_-_ano_2015_23102015_0848.pdf > . Acesso em: 25 jul. 2015.

46 RÊGO, Nelson Melo de Moraes (Coord.). Violência doméstica contra a mulher: dados estatísticos da vara especializada da comarca de São Luis. São Luís: Vara especial de violência doméstica e familiar contra a mulher, 2015. Disponível em: <http:/gerenciador.tjma.jus.br/app/webroot/files/publicacao/407035/ dados_estatosticos_da_vara_especializada_da_comarca_de_soo_luos_-_ano_2015_23102015_0848.pdf > . Acesso em: 25 jul. 2015.

47 WAISELFISZ, Julio Jacobo. Mapa da violência 2015: homicídio de mulheres no Brasil. Rio de Janeiro: FLACSO Brasil, 2015. Disponível em: <www.mapadaviolencia.org.br>. Acesso em: 20 dez. 2015. 


\title{
THE PERFORMANCE OF POLICE AUTHORITIES AND THE JUDICIARY IN COMBATING DOMESTIC VIOLENCE AGAINST WOMEN IN THE CITY OF SÃO LUIS/MA
}

\begin{abstract}
In view of the increasing numbers in cases of domestic violence against women and of the large deficit of studies focused on an evaluation of the structure of public policies at local levels and their effects to curb gender violence, this article aims at conducting a collection of information and data relating to the services and activities of the Special Police Station for Women and the Specialized Jurisdiction on Women and Domestic Violence, in San Luis/MA, which are responsible, respectively, for attending to victims and judging possible crimes of domestic violence against women, to discuss the main difficulties encountered by these bodies in performing their duties. It became clear that the assistance to women victims of domestic or family violence requires a specific technical qualification, since it demands the performance of transdisciplinary activities by those who act against the aforementioned phenomenon in the Special Police Stations and in the Specialized Jurisdiction. Furthermore, it was concluded that the Specialized Jurisdiction for Domestic and Family Violence against Women of the City of São Luís/ MA needs to reframe its actions taking into account the inexpressive number of cases in which there have been merit decisions and final convictions since its creation in 2008. To focus only on granting urgent protective measures, and considering such actions as being enough, is excessively restricting the scope of protection that Law 11.340/2006 aims at achieving. Without procedural instructions which explicitly translate the transdisciplinary nature of the phenomenon of gender violence in its specificity and complexity, there are no effective guarantees for the protection of women victims of violence - or the achievement of justice.
\end{abstract}

Keywords: Domestic violence. Police Authorities. Judiciary Power. São Luis / MA.

Submetido: 18 jun. 2016.

Aprovado: 15 mar. 2017 